\title{
Öğrenme Güçlüğü Tanısı Olan 7-12 Yaş Arasındaki Çocukların İnsan Figürü Çizimlerinin İncelenmesi
}

\section{Mehmet Güney ${ }^{1}$ \\ Emrullah Can Yavuz ${ }^{2 *}$ \\ Dr. Taşkın Taştepe ${ }^{3}$}

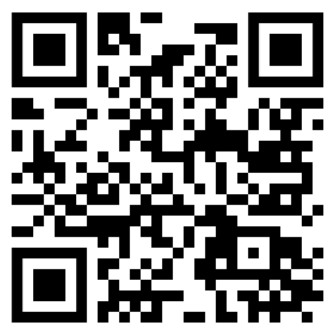

Geliş tarihi: 01.10.2020

Kabul tarihi: 23.11 .2020

\section{Atıf bilgisi:}

IBAD Sosyal Bilimler Dergisi

Sayı: Özel Sayı Sayfa: 462-472

Yil: 2020

This article was checked by Turnitin. Similarity Index $30 \%$

Bu makalede araştırma ve yayın etiğine uyulmuştur.

\footnotetext{
${ }^{1}$ Kırıkkale Üniversitesi, Türkiye, guney.akademik@gmail.com ORCID ID 0000-0002-0962-5643

${ }^{2}$ Kırklareli Üniversitesi, Türkiye, ecanyavuz@gmail.com,

ORCID ID 0000-0001-8243-5478

${ }^{3}$ Ankara Üniversitesi, Türkiye, taskintastepe@gmail.com

ORCID ID 0000-0003-2603-4041
}

* Sorumlu yazar öz

Bu araştırmada öğrenme güçlüğü tanısına sahip olan yedi-on iki yaş arasındaki çocukların insan figürü çizimlerinin çeşitli değişkenler açısından incelenmesi ve çocukların beklenen performans ile gözlenen performansları arasında farklılıklar olup olmadığının incelenmesi amaçlanmıştır. Betimsel araştırma modellerinden kesitsel araştırma modeli kullanılarak yürütülen araştırmanın çalışma grubunu Ankara ilinde özel eğitim ve rehabilitasyon merkezine devam eden ve öğrenme güçlüğü tanısı almış yedi-on iki yaş arasındaki 47 çocuk oluşturmaktadır. Araştırma verileri araştırmacılar tarafından oluşturulan demografik özelliklere ilişkin değişkenleri içeren "Çizim Analiz Formu" ve "Koppitz Bir İnsan Çiz Testi” kullanılarak toplanmıștır. Araştırma sonucunda; öğrenme güçlüğü tanısı olan çocukların gözlemlenen performanslarının beklenen insan figürü çizimlerinin altında kaldığı, erkeklerin çizimlerinde kaş, kirpik ve giyim gibi çevresel faktörlerden etkilenen alanların kızlara göre daha az yer aldığı, eğitim seviyesi ve yaşın ilerlemesiyle insan çizimindeki eksik parçaların azaldığı tespit edilmiştir.

Anahtar Kelimeler: Öğrenme güçlüğü, insan figürü çizimi, çocuk resimleri 


\section{Investigation of the Human Figure Drawings of Children between 7-12 Years with Diagnosis of Learning Difficulty}

\author{
Mehmet Güney ${ }^{1}$ \\ Emrullah Can Yavuz ${ }^{2 *}$ \\ Dr. Taşkın Taştepe ${ }^{3}$
}

First received: 01.10 .2020

Accepted: 23.11 .2020

\section{Citation:}

IBAD Journal of Social Sciences

Issue: Special Issue $\quad$ Pages: 462-472 Year: 2020

This article was checked by Turnitin. Similarity Index $30 \%$

${ }^{1}$ Kurkkkale University, Turkey, guney.akademik@gmail.com ORCID ID 0000-0002-0962-5643

${ }^{2}$ Kurklareli University, Turkey, ecanyavuz@gmail.com,

ORCID ID 0000-0001-8243-5478

${ }^{3}$ Ankara University, Turkey,

taskintastepe@gmail.com

ORCID ID 0000-0003-2603-4041

\section{* Corresponding Author}

\begin{abstract}
In this study, it was aimed to examine human figure drawings of children between the ages of 7 and 12 with a diagnosis of learning difficulty in terms of various variables and to examine whether there are differences between the expected performance and observed performance of children. The study group of the research, which is carried out using a cross-sectional research model, one of the descriptive research models, consists of 47 children between the ages of 7 and 12 who have attended a special education and rehabilitation center in Ankara and diagnosed with learning difficulty. The research data were collected by using the "Drawing Analysis Form", created by the researchers, which includes variables related to demographic characteristics and the "Koppitz Draw a Person Test". As a result of the research, it was determined that the observed performances of children with a diagnosis of learning difficulty were below the expected human figure drawings, the areas affected by environmental factors such as eyebrows, eyelashes and clothing were included in the drawings of boys less than girls, and the missing parts in the human drawing decreased with the advancement of education level and age.
\end{abstract}

Anahtar Kelimeler: Learning Difficulty, human figure drawings, child drawings 


\section{GİRIŞ}

Resim, çocuğun kişiliğini anlamak, zihinsel ve çevresel özellklerine ilişkin bilgi edinmek konusunda yardımcı olan etkili bir araçtır. Sözcüklerin ifade ettiği anlamların ötesine geçebilen çocuk resimleri, çocuğun iç dünyası ve gelişim süreci ile ilgili bilgi vermekte çocuğu tanıma ve anlama süreçlerinde yardımcı olmaktadır (Diğler, 2018). Çocuklar çevrelerinde duydukları, gördükleri, deneyimledikleri durumlara ilişkin zihinlerinde oluşan temsilleri kâğıda aktararak kendi sanat dillerini oluşturmaktadır. $\mathrm{Bu}$ süreç içerisinde algısal gelişim, olgunlaşma ve deneyimlerle birlikte çocuklar var olan becerileri arasına yenilerini ekleyerek gelişim süreçlerini sürdürmektedirler. Renkleri öğrenmekte, sembolleri ve şekilleri tasarlayarak kâğıda yansımalarını görmekte, kendi yorumlarını katarak ürünler ortaya çıkarmaktadır. Çocukların gelişim süreçlerine bağlı olarak çizim becerilerinde farklılıklar meydana gelmekte ve temel düzeyden ileri düzeylere doğru giden bir süreç gözlenmektedir (Artut, 2017). Çocukların yaş ve gelişim özellikleri doğrultusunda çizgisel gelişimlerine bağlı olarak insan figürü çizimleri de değişmekte ve gerçeğe yaklaşmaktadır (Dağlığlu, 2014). Başlangıçta çok fazla eksiğin bulunduğu insan figürü çizimleri yaşa bağlı olarak gelişmekte ve beş-yedi yaş arasında gerçeğe yakın olmaya başlamaktadır. Dokuz-on iki yaş arasında insan figürü çizimleri anatomiye uygun ve oldukça ayrıntılı çizilmektedir. Çocuklar, çizimlerinde cinsiyet farklılıklarını göz önünde bulundurarak erkek ve kız kıyafetlerini ayrıntı olarak belirgin bir şekilde çizimlerine yansıtmaktadır (Yavuzer, 2017). Geçen (2018) gelişim süreci ve büyümenin çocukların figürlerinde meydana getirdiği değişiklikleri incelediği araştırmasında çocukların fiziksel ve bedensel gelişimlerine paralel olarak resimde yer alan figürlerin formsal oluşumunun değiştiği ve etkilendiği, bilişsel ve toplumsal gelişime bağlı olarak ise resimde zengin bir anlatım ve içeriğe yer verdikleri sonucuna ulaşmıştır. Çocukların çizim becerileri üzerinde etkili olan yaş, büyüme ve olgunlaşmanın yanı sıra algısal, görsel motor koordinasyon boyutlarını ele alan araştırma sonuçlarına bakıldığında; görsel motor koordinasyonun çocukların çizim becerileri üzerinde doğrudan bir etki yarattığı, çocuğun yaşına ek olarak görsel alg1, görsel motor koordinasyon becerileri ve sözel becerilerinin çizim becerileri üzerinde etkili olan faktörler arasında yer aldığı görülmektedir (Senese vd., 2020). Koppitz (1966) araştırmasında çocukların insan figürü çizimlerinde parçaların bütünleşme ve birleşmesinde zayıflık olduğunu, eğik figürlerin yer aldığı, vücut ve kol parçalarının ihmal edildiği bulgularına ulaşmıştır. İlkokul yıllarında çocukları tarama açısından önemli olacağını ifade ettiği insan figürü çizimi testinin potansiyel öğrenme problemlerini de erken dönemde fark etme açısından önemli olduğunu belirtmiştir.

Dinleme, konuşma, okuma, yazma, akıl yürütme veya matematiksel becerileri edinme ve kullanma zorluğu yaşayan çocukları nitelemek için kullanılan öğrenme güçlüğü terimi çocukların zekâ sevilerinden bağımsız olarak öğrenme alanında yaşadıkları birtakım sorunlara atıfta bulunmaktadır (National Joint Committee on Learning Disabilities, 2016). Öğrenme güçlüğü tanısına sahip olan çocukların görsel algı ve tarama, el göz koordinasyonu, işler bellek, odaklanmış bellek gibi bilişsel işlev becerilerinde ve mekânsal ilişkileri doğru biçimde algılama konusunda yaşadıkları güçlükler bu sorunların arasında yer almaktadır. Bununla birlikte öğrenme süreçlerinde aktif olarak kullandıkları, yazılı anlatım, kopyalama ve çizim becerileri üzerinde etkili olmaktadır (Bender, 2016). Literatürde yer alan araştırma sonuçlarına da yansıyan bu sorunlar öğrenme güçlüğü tanısına sahip olan çocukların çizim becerileri üzerindeki etkilerini ortaya koymaktadır. Özat (2010) öğrenme güçlüğü tanısına sahip olan öğrencilere yönelik uyguladığı resim dersi eğitimine dayalı görsel alg1 eğitim programının çocukların göz-motor koordinasyon, şekil-zemin ve mekân-konum algısı gibi görsel algılama becerisinin alt basamaklarında ilerlemeler meydana geldiği ve istatistiksel olarak anlamlı sonuçlar ortaya çıkardığ 1 sonucuna ulaşmıştır. Bir başka araştırmada ise öğrenme güçlüğü tanısına sahip olan ve olmayan öğrencilerin çizim becerileri ölçüm ve analizler yapan özel düzeneklerle deneysel desende incelenmiş ve öğrenme güçlüğü tanısına sahip olan çocukların kopyalama, yatay ve dikey çizgi çizme becerilerinde hata oranlarının daha yüksek çıktığı, şekillerde formsal bozulmaların meydana geldiği ve çizgilerde eğiklikler olduğu gözlemlenmiş̧tir (Galli vd., 2011). Öğrenme güçlüğü tanısına sahip olan bir grup çocuğa uygulanan saat çiz testi sonucunda çocukların en fazla saat kadranına sayıları yerleştirmede hata yaptıkları, akrep ve yelkovan gibi saatin bileşenlerini çizmeyi unuttukları, sayıları saat yönü sırasına uygun olarak yerleştirme sorunu yaşadıkları ortaya çıkmıştır. Araştırmacılar, çocukların yaşadıkları bu sorunların öğrenme güçlüğü tanısının genel eşlikçilerinden olan bilişsel çarpıtma ve dikkatin dağınık olması durumlarından kaynaklandığı ifade ederek bu testin öğrenme sorunlarının erken tespiti ve 
müdahalesinde kullanılabileceğini belirtmiştir (Khalifeh, Pezeshk ve Sharifi, 2017). Geçmişten günümüze çocuk resimleri çocuğu tanıma, gelişimini izleme ve değerlendirme gibi birçok amaçla kullanılmaktadır (Yavuzer, 2017). Yapılan araştırma sonuçları göz önünde bulundurulduğunda, çocuk resimleri çocukların gelişim alanları ve yaşından beklenen gelişimsel görevlerin çocuktaki yansımaları hakkında önemli ip uçları vermektedir. Bu nedenle çocuk resimlerini değerlendirme aracı olarak kullanmak, normalden sapmaların olduğu durumları tespit ederek müdahale etmek ve çocukların gelişimlerini desteklemek açısından oldukça önemlidir.

Çocukların çizim gelişim evreleri göz önünde bulundurulduğunda basit karalamalardan sonra insan figürü çizimine doğru bir gelişim gösterdiği görülmektedir. Öncelikler kafadan aşağıya doğru sarkan kollar ve çöp adam çizimleri ile başlayan bu süreçte insan figürü çizimlerinin içerisine geometrik şekillerde girmeye başlayarak (yuvarlak kafa, kare ve üçgen gövde gibi), el ve parmak çizimleri gibi detaylarla süreç devam etmektedir (Yavuzer, 2017). Çocukların insan figürü çizimlerinde görülen bu aşamalar kullandıkları çizgisel formlar öğrenme güçlüğü tanısı olan çocukların çizim becerileri ve bu alanda yaşadıkları güçlükleri de ortaya koyacağı düşünülerek çizim becerilerinin insan figürü çizimleri üzerinden incelenmesinin önemli bulgular ortaya çıkaracağı düşünülmektedir. Bu araştırmada öğrenme güçlüğü tanısına sahip olan yedi-on iki yaş arasındaki çocukların insan figürü çizimlerinin çeşitli değişkenler açısından incelenmesi ve çocukların beklenen performans ile gözlenen performansları arasında farklılıklar olup olmadığının incelenmesi amaçlanmıştır. Öğrenme güçlüğü tanısı olan çocukların okuma-yazma, düşüncelerini ve gördüklerini kâğıda aktarma gibi kendini ifade etme süreçlerinin motor beceri, görsel algılama ve çizim becerilerinden etkilenmesinden yola çıkılarak öğrenme güçlüğü tanısı olan öğrencilerin yaşadıkları görsel algılama, mekân zemin ilişkisi, motor beceri zayıflı̆̆ sorunlarının çocukların çizimlerindeki yansımalarını gözlemlemek amaçlanmıştır.

\section{YÖNTEM}

\subsection{Araştırmanın Modeli}

Araştırmada, verilen bir durumu ortaya koymak, incelemek ve ilişkileri aydınlatmak için kullanılan betimsel araştırma modellerinden kesitsel araştırma modeli kullanılmıştır. Tarama modelinin alt türlerinden olan kesitsel araştırma modelinde aynı zaman dilimi içerisinde benzer özelliklerdeki farklı gruplar ile çalışma gerçekleştirilmektedir (Büyüköztürk, 2018; Can, 2019). Zaman faktörünün etki etmediği o andaki verileri içerdiği için bu çalışmada bu model tercih edilmiştir.

\section{2. Çalışma Grubu}

Araştırmanın çalışma grubu, Ankara ilinde özel eğitim ve rehabilitasyon merkezine devam eden ve öğrenme güçlügü tanısı almış yedi-on iki yaş arasındaki 47 çocuktan oluşmaktadır. Çalışma grubuna dâhil olan çocuklarda gönüllülük, ek engel (otizm, down sendromu, zihinsel yetersizlik vb.) olmamas1 ve öğrenme güçlüğü destek eğitim programından yararlanmaları göz önünde bulundurulmuştur.

\subsection{Veri Toplama Aracı}

Araştırmacılar tarafından oluşturulan demografik özelliklere ilişkin değişkenleri içeren "Çizim Analiz Formu” ve "Koppitz Bir İnsan Çiz Testi” kullanılarak ve Mart 2018-Mayıs 2018 aralığında toplanmıştır.

\subsubsection{Koppitz Bir İnsan Çiz Testi}

Koppitz (1968) tarafından gelişimsel ve duygusal özellikler dikkate alınarak beş-on iki yaş çocukların çizimlerini incelemek için geliştirilmiştir. Çizimlerde aşağıda yer alan 30 kriter dikkate alınmaktadır. Bunlar;
1. Kafa
11. Boyun
21. Bacaklar
2. Gözler
12. Vücut
22. İki taraflı bacaklar
3. Göz bebekleri
13. Kollar
23. Dizler
4. Kaşlar ve kirpikler
14. İki taraflı kollar
24. Ayaklar 

5. Burun
15. Aşağı doğru inen kollar
25. İki taraflı ayak
6. Burun delikleri
16. Omuzdan çıkan kollar
26. Profil
7. Ağ1z
17. Dirsekler
27. İyi oran
8. Çift dudak
18. Eller
28. Giyim/bir özellik veya hiçbiri
9. Kulaklar
19. Parmaklar
29. Giyim/iki-üç özellik
10. Saç
20. Doğru sayıda parmaklar
30. Giyim/dört-beş özellik

Test, puanlama sistemi ile zekâ yordaması için kullanılabildiği gibi sıklıkla yukarıdaki boyutların var olup olmamasına göre de değerlendirilmektedir. Koppitz (1968) tarafindan beklenen, gözlenen, olağan ve olağandışı olarak gruplandırılan bu yöntemde yaşa ve cinsiyete göre beklenen kriterlerin olup olmaması göz önünde bulundurulmaktadır. Beklenen durum, o yaş aralığındaki çocukların \%86-\%100'ü arasında o boyutun çizimlerinde görüldügü anlamına gelmektedir. En alt düzeyde o yaş aralığında olması gereken boyutun olmaması önem arz etmektedir (Dağlığlu, 2014).

\subsection{2. Çizim Analiz Formu}

Uygulamacılar tarafından oluşturulan Çizim Analiz Formu'nda, çocukların uygulama kodları (F1, F2 gibi), yaş, cinsiyet, sınıf düzeyi gibi bilgilerin yanı sıra uygulamacıların çocukların çizdiği resimler hakkındaki analiz sonuçlarını not aldığı çizim analizi bölümü yer almaktadır. Uygulamacılar bu formu kullanarak çocukların çizim yapma esnasındaki çizim davranışlarını, aktardığı düşünceleri de not alarak çizim sürecinde gözlenen becerileri kodlamaktadır.

\subsection{Veri Toplama Süreci}

Araştırma verileri toplanmadan önce çocuklarla görüşülerek araştırmanın amacı ve içeriği anlatılmıştır. Daha sonra araştırmaya gönüllü olarak dâhil olmak isteyen çocuklarla uygulamaya başlanmıştır. Araştırmaya katılan her bir çocuk ile bireysel olarak görüşme yapılmış ve her görüşmede sadece bir çocuk ve bir uygulamacı olacak şekilde uygulama ortamı düzenlenmiştir. Uygulama esnasında çocuklara kullanabilmeleri için kalem, kâğıt ve boya gibi çizim materyalleri sunulmuş ve "Bir insan resmi çizmeni istiyorum. Çizebildiğin en detaylı insan resmi olsun" yönergesiyle çocukların çizim yapmaları istenmiştir. Uygulama esnasında çocukları rahatlatmak ve gerçek performanslarını sergileyebilmeleri adına çizdikleri resimlerin belirli bir kalıbının olmadığı, kendi hayal ettikleri insan figürü çizimlerini kâğıda yansıtmalarını ve yaptıkları çizimin doğru, yanlış veya eksik olarak değerlendirilmeyeceği belirtilmiş sadece detaylı olarak bir insan çizmeleri istenerek veriler toplanmıştır.

\subsection{Verilerin Analizi}

Araştırmacılar tarafından özel eğitim ve rehabilitasyon merkezlerindeki gönüllü çocuklar ile gerçekleştirilen çalışmalarda demografik bilgiler alınmış, sonrasında çizebildikleri en iyi insan resmini çizmeleri istenmiştir. Resimlerden elde edilen veriler uygun istatistiksel yöntemler ile araştırmacılar tarafından analiz edilmiş ve araştırmacılar arası güvenirlik \%95,7 olarak bulunmuştur. Araştırmanın güvenirliği hesaplanırken Miles ve Huberman'ın (1994) önerdiği "Güvenirlik= (Görüş Birliği/Görüş Birliği + Görüş Ayrılığı)x100” formülü kullanılmıştır. İnsan figürünün alt boyutlarında cinsiyet, sınıf grubu ve yaş grubuna göre beklenen frekansla gözlemlenen frekans karşılaştırılıp, değişkenler arası iliş̧iyi sorgulamak için paremetrik olmayan testlerden "İki Yönlü Ki-Kare Testi” yapılmıştır. Testin ön koşulları olan, alt grupların en az \%80'inde beklenen değeri beşin altında hücre olmamasına, serbestlik derecesinin 1 olduğu durumlarda süreklilik düzeltmesinin yapılmasına dikkat edilerek uygun koşullardaki veriler analiz edilmiştir (Can, 2019). Bununla birlikte testte yer alan Koppitz (1968) tarafından beklenen ölçütlerin yaş ve cinsiyete göre olma durumuna ilişkin frekans tablosu oluşturulmuştur. 


\section{BULGULAR}

Koppitz'in bir insan çiz testinde yaş ve cinsiyetlere göre beklenen ölçütlerin çalışma grubundaki ögrenme güçlüğü olan çocukların resimlerinde bulunma yüzdesine ilişkin bulgular Tablo 1'de sunulmuştur.

Tablo1. Yaşa ve Cinsiyete Göre Beklenen Ölçütlere İlişkin Frekans Tablosu

\begin{tabular}{|c|c|c|c|c|c|c|c|c|c|c|c|c|}
\hline \multirow[b]{2}{*}{ Beklenen } & \multicolumn{2}{|c|}{7 Yaş } & \multicolumn{2}{|c|}{8 Yaş } & \multicolumn{2}{|c|}{9 Yaş } & \multicolumn{2}{|c|}{10 Yaş } & \multicolumn{2}{|c|}{11 Yaş } & \multicolumn{2}{|c|}{12 Yaş } \\
\hline & $\mathrm{K}_{12}$ & Erkek & $\mathrm{K} 1 \mathrm{z}$ & Erkek & $\mathrm{K}_{12}$ & Erkek & $\mathrm{K}_{1 \mathrm{z}}$ & Erkek & $\mathrm{K} 1 \mathrm{z}$ & Erkek & $\mathrm{K}_{1 z}$ & Erkek \\
\hline Baş & $\% 100$ & $\% 66,7$ & $\% 100$ & $\% 100$ & $\% 100$ & $\% 100$ & $\% 100$ & $\% 100$ & $\% 100$ & $\% 100$ & $\% 100$ & $\% 100$ \\
\hline Gözler & $\% 100$ & $\% 33,3$ & $\% 100$ & $\% 100$ & $\% 100$ & $\% 90,9$ & $\% 100$ & $\% 100$ & $\% 100$ & $\% 100$ & $\% 100$ & $\% 100$ \\
\hline Burun & $\% 50$ & $\% 33,3$ & $\% 33,3$ & $\% 33,3$ & $\% 100$ & $\% 45,5$ & $\% 66,7$ & $\% 60$ & $\% 50$ & $\% 33,3$ & $\% 100$ & $\% 66,7$ \\
\hline A $\breve{g ̆}_{1 Z}$ & $\% 100$ & $\% 0$ & $\% 100$ & $\% 100$ & $\% 100$ & $\% 100$ & $\% 100$ & $\% 100$ & $\% 100$ & $\% 83,3$ & $\% 100$ & $\% 100$ \\
\hline Vücut & $\% 100$ & $\% 66,7$ & $\% 66,7$ & $\% 66,7$ & $\% 100$ & $\% 72,7$ & $\% 100$ & $\% 80$ & $\% 50$ & $\% 66,7$ & $\% 100$ & $\% 83,3$ \\
\hline Bacaklar & $\% 100$ & $\% 66,7$ & $\% 66,7$ & $\% 100$ & $\% 100$ & $\% 90,9$ & $\% 66,7$ & $\% 100$ & $\% 100$ & $\% 83,3$ & $\% 100$ & $\% 66,7$ \\
\hline Kollar & $\% 100$ & $\% 33,3$ & $\% 66,7$ & $\% 100$ & $\% 100$ & $\% 90,9$ & $\% 100$ & $\% 100$ & $\% 100$ & $\% 100$ & $\% 100$ & $\% 100$ \\
\hline Ayaklar & $\% 100$ & $\% 33,3$ & $\% 66,7$ & $\% 66,7$ & $\% 100$ & $\% 63,9$ & $\% 66,7$ & $\% 40$ & $\% 75$ & $\% 50$ & $\% 100$ & $\% 50$ \\
\hline $\begin{array}{l}\text { İki Taraflı } \\
\text { Kollar }\end{array}$ & $\% 100$ & $\% 33,3$ & $\% 66,7$ & $\% 100$ & $\% 100$ & $\% 90,9$ & $\% 100$ & $\% 100$ & $\% 100$ & $\% 83,3$ & $\% 100$ & $\% 100$ \\
\hline $\begin{array}{l}\text { İki Taraflı } \\
\text { Bacaklar }\end{array}$ & $\% 100$ & $\% 66,7$ & $\% 66,7$ & $\% 100$ & $\% 100$ & $\% 90,9$ & $\% 100$ & $\% 66,7$ & $\% 100$ & $\% 83,3$ & $\% 100$ & $\% 66,7$ \\
\hline Saç & $\% 100$ & $\% 33,3$ & $\% 100$ & $\% 100$ & $\% 100$ & $\% 100$ & $\% 100$ & $\% 80$ & $\% 100$ & $\% 100$ & $\% 100$ & $\% 100$ \\
\hline Boyun & $\% 100$ & $\% 0$ & $\% 0$ & $\% 66,7$ & $\% 100$ & $\% 66,7$ & $\% 100$ & $\% 80$ & $\% 50$ & $\% 83,3$ & $\% 100$ & $\% 66,7$ \\
\hline $\begin{array}{l}\text { Aşağ1 Doğru } \\
\text { İnen Kollar }\end{array}$ & $\% 0$ & $\% 0$ & $\% 33,3$ & $\% 33,3$ & $\% 100$ & $\% 9,1$ & $\% 100$ & $\% 40$ & $\% 50$ & $\% 16,7$ & $\% 100$ & $\% 83,3$ \\
\hline $\begin{array}{l}\text { Omuzdan } \\
\text { Çıkan Kollar }\end{array}$ & $\% 0$ & $\% 0$ & $\% 0$ & $\% 66,7$ & $\% 100$ & $\% 9,1$ & $\% 66,7$ & $\% 0$ & $\% 50$ & $\% 33,3$ & $\% 100$ & $\% 66,7$ \\
\hline $\begin{array}{l}\text { Giyim (2-3 } \\
\text { özellik) }\end{array}$ & $\% 100$ & $\% 0$ & $\% 33,3$ & $\% 66,7$ & $\% 100$ & $\% 18,2$ & $\% 66,7$ & $\% 40$ & $\% 50$ & $\% 33,3$ & $\% 100$ & $\% 50$ \\
\hline
\end{tabular}

$\square$ Kızlar için beklenen ölçütler $\square$ Erkekler için beklenen ölçütler

Tablo 1'de beklenen ölçütler incelendiğinde öğrenme güçlüğü olan çocuklar, özellikle erkekler, birçok boyutta \%86'nın altında kalmaktadır. Başın her yaş grubunda büyük çoğunluk veya tamamı tarafından resmedildiği görülürken, gözlerin yedi yaş erkeklerde beklenen bir ölçüt olmasına rağmen yalnızca \%33,3'ü tarafından resmedildiği görülmektedir. Burun ölçütüne bakıldığında yedi yaşındaki erkeklerde $(\% 33,3)$, sekiz yaşındaki kız ve erkeklerde $(\% 33,3)$, dokuz $(\% 45,5)$ ve on bir $(\% 33,3)$ yaşındaki erkeklerde nadiren görülmektedir. Ağız çizimleri ise yedi yaş erkek çocuklarının hiçbirinin resminde yer almamıştır. Beklenen kriterlerde kol çizimi yedi yaşındaki erkeklerin yalnızca \%33'ünün resminde yer alırken, ayak çizimi ise yedi yaş erkeklerin \%33,3'ünde, on yaş erkeklerin de \%40'ında yer almaktadır. Yedi yaşındaki erkeklerin büyük çoğunluğunun resimlerinde iki taraflı kollar resmedilmezken, benzer bir durum aşağ 1 doğru inen kol çiziminde on ve on bir yaş erkeklerde de görülmektedir.

Tablo 1 çerçevesinde çocukların çizdiği insan figürlerinden örnekler incelendiğinde, Resim-1'de on yaşındaki bir erkek çocuktan beklenenin üzerinde giyim özellikleri gibi unsurlara yer verirken beklenen burun, ayak ve aşağ 1 doğru inen kollar gibi temel unsurlar çizimde görülmemektedir. Benzer şekilde Resim-2 incelendiğinde, dokuz yaşında bir erkek çocuk resminden beklenen burun ve ayak gibi unsurlar yer almamaktadır. Resim-3’te yedi yaşında bir kız çocuğunun resminden beklenen unsurlardan sadece 
vücut çizimi eksik görülürken, Resim-4'e bakıldığında on bir yaşındaki kız çocuğunun çiziminde burun, vücut, boyun, giyim, omuzdan çıkan ve aşağı doğru inen kol gibi beklenen birçok unsur eksiktir.

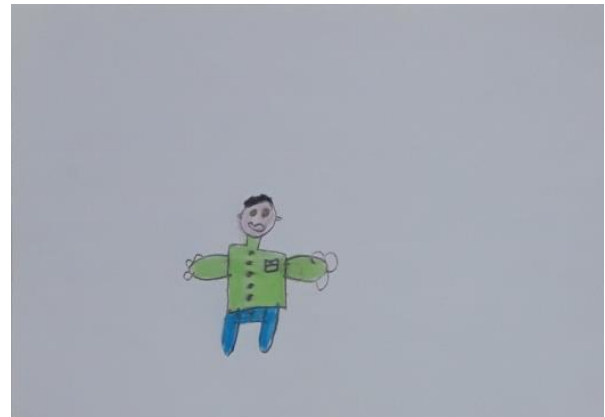

Resim 1. Erkek- 10 yaş

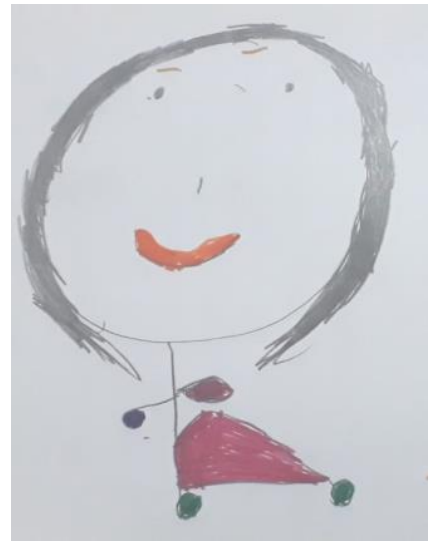

Resim 3. Klz- 7 yaş

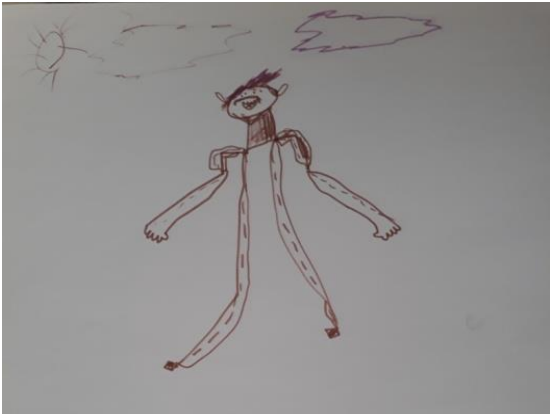

Resim 2. Erkek- 9 yaş

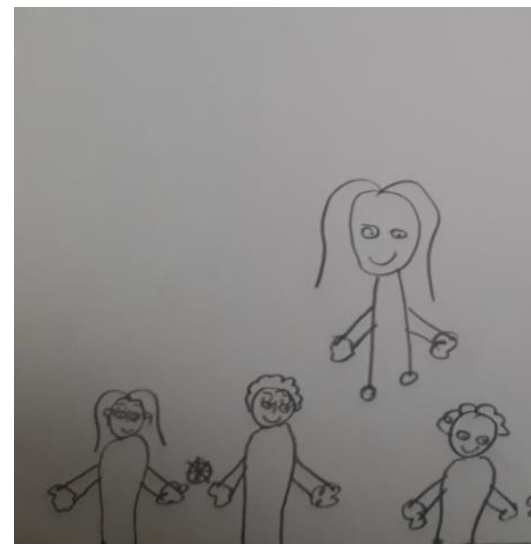

Resim 4. Klz- 11 yaş

Çalışmaya katılan çocukların cinsiyet değişkenlerine göre çizimlerinin incelenmesine ilişkin bulgular Tablo 2'de sunulmuştur.

Tablo2. Çocukların İnsan Figürü Çizimlerinin Cinsiyet Değişskenine Göre İncelenmesi

\begin{tabular}{|c|c|c|c|c|c|c|c|c|}
\hline \multirow{2}{*}{ Boyutlar } & & \multicolumn{2}{|c|}{$\mathrm{K} 1 \mathrm{Z}$} & \multicolumn{2}{|c|}{ Erkek } & \multirow{2}{*}{$\phi$} & \multirow{2}{*}{$X^{2}$} & \multirow{2}{*}{$\mathrm{p}$} \\
\hline & & $\mathrm{n}$ & $\%$ & $\mathrm{n}$ & $\%$ & & & \\
\hline \multirow{2}{*}{ Kaşlar ve Kirpikler } & Var & 10 & 71,4 & 7 & 20,6 & \multirow{2}{*}{,483 } & \multirow{2}{*}{9,09} & \multirow{2}{*}{, 001} \\
\hline & Yok & 4 & 28,6 & 27 & 79,4 & & & \\
\hline \multirow{2}{*}{ Giyim-İki üç özellik } & Var & 9 & 64,3 & 11 & 32,4 & \multirow{2}{*}{,294 } & \multirow{2}{*}{2,95} & \multirow{2}{*}{, 041} \\
\hline & Yok & 5 & 35,7 & 23 & 67,6 & & & \\
\hline \multirow{2}{*}{ Giyim-Dört beş özellik } & Var & 5 & 35,7 & 3 & 8,8 & \multirow{2}{*}{,328 } & \multirow{2}{*}{3,40} & \multirow{2}{*}{, 023} \\
\hline & Yok & 9 & 64,3 & 31 & 91,2 & & & \\
\hline
\end{tabular}

Tablo 2 incelendiğinde, insan çizimlerinde kaşlar ve kirpiklerin çizimiyle öğrenme güçlüğü olan çocukların cinsiyeti arasında orta düzeyde anlamlı bir ilişkisi olduğu görülmektedir $\left[X^{2}(1, n=48)=9,09\right.$; $\mathrm{p}=, 001 ; \phi=, 483]$. Giyim özellikleri incelendiğinde en az iki üç kıyafet çiziminin olup olmaması durumu cinsiyet ile anlamlı ancak çok düşük düzeyde bir ilişki göstermektedir $\left[X^{2}(1, n=48)=2,95 ; p=, 041\right.$; $\phi=$,294]. Dört-beş giyim özelliği çizimleri ile cinsiyet arasında da benzer bir şekilde düşük düzeyde anlamlı bir ilişki vardır $\left[X^{2}(1, \mathrm{n}=48)=3,40 ; \mathrm{p}=, 023 ; \phi=, 328\right]$. Anlamlı fark bulunan insan çizimi alt boyutlarının tamamında kız çocuklarında görülme yüzdesi erkeklerin resimlerindekine göre daha yüksektir. 
İlkokul ve ortaokula devam etmesine göre gruplanan katılımcıların çizimlerine ilişkin bulgular Tablo 3'de sunulmuştur.

Tablo 3. Çocukların İnsan Figürü Çizimlerinin Sinıf Değişkenine Göre İncelenmesi

\begin{tabular}{|c|c|c|c|c|c|c|c|c|}
\hline \multirow{2}{*}{ Boyutlar } & & \multicolumn{2}{|c|}{ İlkokul } & \multicolumn{2}{|c|}{ Ortaokul } & \multirow{2}{*}{$\phi$} & \multirow{2}{*}{$X^{2}$} & \multirow{2}{*}{$\mathrm{p}$} \\
\hline & & $\mathrm{n}$ & $\%$ & $\mathrm{n}$ & $\%$ & & & \\
\hline \multirow{2}{*}{ Göz Bebekleri } & Var & 5 & 21,7 & 15 & 60,0 & \multirow{2}{*}{, 388} & \multirow{2}{*}{5,73} & \multirow{2}{*}{, 007} \\
\hline & Yok & 18 & 78,3 & 10 & 40,0 & & & \\
\hline \multirow{2}{*}{ Kaşlar ve Kirpikler } & Var & 3 & 13,0 & 14 & 56,0 & \multirow{2}{*}{, 449} & \multirow{2}{*}{7,88} & \multirow{2}{*}{,002 } \\
\hline & Yok & 20 & 87,0 & 11 & 44,0 & & & \\
\hline \multirow{2}{*}{ Çift dudak } & Var & 7 & 20,4 & 15 & 60,0 & \multirow{2}{*}{,296 } & \multirow{2}{*}{3,11} & \multirow{2}{*}{, 040} \\
\hline & Yok & 16 & 69,6 & 10 & 40,0 & & & \\
\hline \multirow{2}{*}{ Boyun } & Var & 9 & 39,1 & 19 & 76,0 & \multirow{2}{*}{, 374} & \multirow{2}{*}{5,27} & \multirow{2}{*}{, 010} \\
\hline & Yok & 14 & 60,9 & 6 & 24,0 & & & \\
\hline \multirow{2}{*}{ Aşağ1 Doğru İnen Kollar } & Var & 4 & 17,4 & 14 & 56,0 & \multirow{2}{*}{,398 } & \multirow{2}{*}{6,06} & \multirow{2}{*}{, 006} \\
\hline & Yok & 19 & 82,6 & 11 & 44,0 & & & \\
\hline \multirow{2}{*}{ Omuzda Çıkan Kollar } & Var & 4 & 17,4 & 11 & 44,0 & \multirow{2}{*}{,287 } & \multirow{2}{*}{2,81} & \multirow{2}{*}{,047 } \\
\hline & Yok & 19 & 82,6 & 14 & 56,0 & & & \\
\hline
\end{tabular}

Tablo 3'e göre çalışmaya katılan çocukların çizimleri incelendiğinde göz bebekleri çiziminin düşük düzeyde sınıf değişkeni ile anlamlı bir ilişkisi bulunmaktadır $\left[X^{2}(1, n=48)=5,73 ; p=, 007 ; \phi=, 388\right]$. Kaş ve kirpik çiziminin insan figürlerinde bulunması ile sınıf grupları arasında, orta düzeyde anlamlı bir ilişki vardır $\left[X^{2}(1, n=48)=7,88 ; \mathrm{p}=, 002 ; \phi=, 449\right]$. İki dudağın birlikte çizilmesi ilkokul ve ortaokul çocukları arasında düşük düzeyde de olsa anlamlı bir şekilde farklılaşmaktadır $\left[X^{2} \quad(1, n=48)=3,11\right.$; $\mathrm{p}=, 040 ; \phi=, 296]$. Boyun çizimi $\left[X^{2}(1, \mathrm{n}=48)=5,27 ; \mathrm{p}=, 010 ; \phi=, 374\right]$ ve aşağı doğru inen kollar $\left[X^{2}(1\right.$, $\mathrm{n}=48)=6,06 ; \mathrm{p}=, 006 ; \phi=, 398]$ ile sınıf grupları arasında ise orta düzeyde anlamlı bir ilişki görülmektedir. İlkokul ve ortaokul çocuklarının omuzdan çıkan kolların çiziminde sınıf grupları ile anlamlı bir ilişki bulunmakta ancak bu ilişki düşük düzeydedir [ $\left.X^{2}(1, n=48)=2,81 ; \mathrm{p}=, 047 ; \phi=, 287\right]$. Anlamlı ilişki bulunan boyutların tamamında ilkokuldan ortaokula doğru ilerledikçe çizimlerde görülme yüzdesi yükselmektedir.

Öğrenme güçlügü olan çocukların yaş gruplarına göre çizimlerinin incelenmesine ilişkin bulgular Tablo 4'de yansitılmaktadir.

Tablo 4. Çocukların Insan Figürü Çizimlerinin Yaş Değişkenine Göre İncelenmesi

\begin{tabular}{|c|c|c|c|c|c|c|c|c|c|c|}
\hline \multirow{2}{*}{ Boyutlar } & \multirow[t]{2}{*}{ Yaş Grubu } & \multicolumn{2}{|c|}{ 7-8 Yaş } & \multicolumn{2}{|c|}{ 9-10 Yaş } & \multicolumn{2}{|c|}{$11-12$ Yaş } & \multirow{2}{*}{ V } & \multirow{2}{*}{$X^{2}$} & \multirow{2}{*}{$\mathrm{p}$} \\
\hline & & $\mathrm{n}$ & $\%$ & $\mathrm{n}$ & $\%$ & $\mathrm{n}$ & $\%$ & & & \\
\hline \multirow{2}{*}{$\begin{array}{l}\text { Kaşlar ve } \\
\text { Kirpikler }\end{array}$} & Var & 3 & 27,3 & 2 & 10,0 & 12 & 70,6 & \multirow{2}{*}{, 562} & \multirow{2}{*}{15,16} & \multirow{2}{*}{,001 } \\
\hline & Yok & 8 & 72,7 & 18 & 90,0 & 5 & 29,4 & & & \\
\hline
\end{tabular}

Tablo 4'e bakıldığında yaş gruplarına göre insan çizimi alt boyutlarından yalnızca kaşlar ve kirpiklerin olup olmama durumu arasında anlamlı bir ilişki bulunmaktadır. Yaş grupları ve kaş, kirpik çizimi arasındaki ilişkinin orta düzeyde olduğu tabloda görülmektedir $\left[X^{2}(2, \mathrm{n}=48)=15,16 ; \mathrm{p}=, 001 ; V=, 562\right]$. 


\section{TARTIŞMA}

Öğrenme güçlüğü tanısı olan çocuklar Koppitz (1968)'in ölçütlerinde yer alan yüzdelerin altında kalmaktadır. Özellikle erkeklerin birçok yaş grubunda ölçütleri karşılayamadığı görülürken, kızların da erken yaşlarda ölçütlerin altında kaldığı, ilerleyen yaş ile yaşıtlarına uyum gösterdiği görülmektedir. Çizimdeki burun, boyun gibi daha ayrıntılı boyutların çizimlerde görülme yüzdesi daha da düşmektedir. Çizimlerde vücut bölümlerinin baştan ayağa doğru azaldığı, vücut kol ve ayaklardaki ayrıntılara daha az dikkat edildiği bulunmuştur. Öğrenme güçlüğü tanısı olan çocukların çizim becerilerinin daha zayıf olduğuna ilişkin çalışmalar alan yazında sıklıkla yer almaktadır. Öğrenme güçlüğü olan çocukların ince motor becerilerinin zayıf olmasından kaynaklı çizim becerilerinin de zayıf olduğu Ibrahim vd. (2019)'nin çalışmasında yer almaktadır. Kashfi vd. (2019)'nin de çalışmasında ince motor becerileri desteklenen çocukların öğrenmenin temelinde olan yürütücü işlev becerilerinde ilerleme olduğu bulunmuştur. Öğrenme güçlüğü olan çocukların çizim becerilerindeki gelişimin incelendiği çalışmada, öğrenme güçlüğü olan çocukların çizgilerinin ve çizgi açılarının daha hatalı olduğu ifade edilmiştir (Galli vd., 2011). Bununla birlikte öğrenme güçlüğü olan çocukların saat çizimlerinin değerlendirilmesinde eksik çizimlerin dikkat eksikliği ve bilişsel çarpıtmalardan kaynaklandığı belirtilmiştir (Khalifeh, Pezeshk ve Sharifi, 2017).

Kız ve erkekler arasında vücudun bölümlerine ilişkin farkın kaş, kirpik ve giyim özelliklerinin çiziminde görülmektedir. Bu durumda akran etkileşiminden kaynaklı çevresel faktörlerin daha etkili olduğu düşünülmektedir. Cox (1998), çocukların çizimlerinin kültürel ve çevresel faktörlerden etkilendiğini ve değişim geçirebildiğini çalışmasında belirtmiştir. Birçok kız çocuğunun resimlerinde eksik uzuvlar olsa da Cox’un belirttiği gibi kültürel öğelere ve aksesuarlara yer verildiği gözlemlenmiştir.

Bu araştırmada ilkokul ve ortaokul eğitimine devam eden çocuklar arasında ise göz bebeği, kaş ve kirpik, çift dudak, boyun, aşağı inen kollar, omuzdan çıkan kollar gibi daha ayrıntılı çizim boyutları arasında fark olduğu görülmektedir. Öğrenme güçlüğü tanısı olan çocukların aldığı eğitimle birlikte yaşıtlarını yakalamasından kaynaklı çizimlerin geliştiği, yaşıtlarıyla arasındaki farkın kapandığı düşünülmektedir. Eğitimin çizim becerileri üzerindeki etkisini yansıtan Özat (2010)'in çalışmasında, öğrenme güçlüğü olan çocukların aldıkları resim eğitimi ile beraber görsel algılama becerilerinde gelişme olduğu belirlenmiştir. Hikâye anlatımının çocuk resimleri üzerindeki etkisinin incelendiği bir diğer araştırmada ise hikâye eğitiminden sonra çocukların resim çizimlerinde anlamlı derecece farklılaşma gözlemlenmiştir (Onuk, 2017)

Erken yıllarda kaş ve kirpik çizimleri resimlerde yer almazken, ileriki yaşlarda daha sık çizimlerde yer almaya başlamıştır. Yaş ile beraber zekâ faktörüyle çocukların çizimleri arasında korelasyonel bir ilişki olduğu Bensur, Eliot ve Hedge (1997)'nin çalışmasında da yer almaktadır. Dağlığlu (2014) da araştırmasında, yaş büyüdükçe çocukların çizimlerinde gelişme olduğunu ifade etmektedir.

\section{SONUÇ VE ÖNERILER}

Öğrenme güçlüğü tanısı olan çocukların insan figürü çizimlerinin, yaşıyla uyumlu gelişim gösteren çocukların insan figürü çizimlerinde görülen gelişim aşamalarına ait özellikleri gösterip göstermediklerini incelemek ve yedi-on iki yaş grubu öğrenme güçlüğü tanısı olan çocukların insan figürü çizimlerinin yaşa göre gelişimsel olarak incelenmesinin amaçlandığı bu araştırmanın sonucunda; öğrenme güçlüğü tanısı olan çocukların beklenen insan figürü çizimlerinin altında kaldığı, bu oranın erkeklerde daha düşük olduğu bulunmuştur.

Erkek çocukların çizimlerinde, kaş, kirpik ve giyim gibi çevresel faktörlerden etkilenen alanların, kız çocukların çizimlerine göre daha az yer aldığ 1 görülmüştür. İnsan figürlerindeki diğer boyutlarda kızlar ve erkekler arasında çizimlerde görülme sıklığı açısında anlamlı bir farklılık bulunmamaktadır. $\mathrm{Bu}$ durumda, çizim sırasında F46'nın "Böyle saç yapmayı arkadaşımdan öğrendim.” ifadesinde olduğu gibi akran etkileşiminin önemli olduğu düşünülmektedir. Bununla birlikte eğitim seviyesi ve yaş arttıkça çocukların çizimlerindeki eksik parçaların azaldığı sonucuna ulaşılmıştır. 
Araştırmanın sonuçları doğrultusunda aşağıdaki öneriler sunulmaktadır:

- Sonraki dönemde yapılacak çalışmalarda daha geniş bir örneklem ile öğrenme güçlüğü olan çocuklar ile yaşıyla uyumlu gelişim gösteren çocukların resimleri arasında karşılaştırma yapılabilir, deneysel bir çalışmada uygulanan programın etkisi değerlendirilebilir.

- Çocukların çizimlerine etki eden çevresel ve gelişimsel değişkenlerin ayrıntılı incelendiği, çocukların kendi çizimlerinin değerlendirilip nitel boyutun dâhil edildiği çalışmalar planlanabilir.

- Öğrenme güçlüğü olan çocukların resimlerinin bilişsel modele göre değerlendirilip ilişkilendirilebileceği bir çalışma hazırlanabilir.

- Öğrenme güçlüğü olan çocukların eğitim ortamına yönelik çizimlerinin yaşıtlarıyla uyumlu gelişim gösteren çocukların çizimleri ile içerik olarak karşılaştırılabilir.

\section{Bilgilendirme / Acknowledgement:}

Yazarlar aşağıdaki billgillend lirmeleri yapmaktadırlar:

1- Araştırmacıların katkı oranı eşittir.

2- Uluslararası IV. Çocuk Gelişimi Kongresi'nde sözlü bildiri olarak sunulmuştur.

3- Makalenin yazarları arasında çıkar çatışması bulunmamaktadır.

4- Araştırma verileri 2018 yılında toplanmış ve yorumlanmıştır.

5- Bu makalede araştırma ve yayın etiğine uyulmuştur.

\section{KAYNAKCA}

Artut, K. (2017). Okul öncesinde resim eğitimi. Ankara: Anı Yayıncılık.

Bender, W. N. (2016). Öğrenme güçlüğü olan bireyler ve eğitimleri. (H. Sarı, Çev. Ed.) Ankara: Nobel Yayınc1lik.

Bensur, B.J., Eliot, J. ve Hedge, L. (1997). Cognitive correlates of complexity of children's drawings. Perceptual and Motor Skills, 85, 1079-1089.

Büyüköztürk, Ş. (2018). Sosyal bilimler için veri analizi el kitabı: istatistik, araştırma deseni, SPSS uygulamalarl ve yorum. 24. Bask1. Ankara: Pegem Yayınc1lık.

Can, A. (2019). SPSS ile bilimsel araştırma sürecinde nicel veri analizi. Ankara: Pegem Yayınc1lık.

Cox, M. (1998). Drawings of people by australian aboriginal children: the intermixing of cultural styles. Journal of Art and Design Education, 17(1), 71-79.

Dağlığlu, H. E. (2014). 5-7 Yaş grubu çocukların insan figürü çizimlerinin gelişimsel açıdan değerlendirilmesi. International Online Journal of Educational Sciences, 6(2), 510-523.

Diğler, M. (2018). Okul öncesinde resim eğitimi. Ankara: Pegem Yayıncılık.

Galli, M., Vimercati, S. L., Stella, G., Caiazzo, G., Norveti, F., Onnis, F., ve Albertini, G. (2011). A new approach for the quantitative evaluation of drawings in children with learning disabilities. Research in developmental disabilities, 32(3), 1004-1010.

Geçen, F. (2018). Çocuğun gelişim basamaklarına göre figürleri ele alma biçimleri. Avrasya Sosyal ve Ekonomi Araştırmaları Dergisi, 5(10), 60-83.

Ibrahim, S., Harun, D., Baharudin, S. ve Hui, E. J. T. (2019). Motor performance and functional mobility in children with specific learning disabilities. Med J Malaysia, 74(1), 35. 
Kashfi, E. T., Sohrabi, M., Saberi Kakhki, A., Mashhadi, A. ve Jabbari Nooghabi, M. (2019). Effects of a motor intervention program on motor skills and executive functions in children with learning disabilities. Perceptual and motor skills, 126(3), 477-498.

Khalifeh, A., Pezeshk, S. ve Sharifi, M. (2017). Clock face drawing in children with learning disabilities: an old problem revisited. International Journal of Psychology, 11(2), 26-47.

Koppitz, E. M. ( 1968). Psychogical evaluation of children's human drawings. New York: Crune and Stratton.

Koppitz, E. M. (1966). Emotional indicators on human figure drawings and school achievement of first and second graders. Journal of clinical psychology, 22(4), 481-483.

Miles, M, B., Huberman, A. M. (1994). Qualitative data analysis: An expanded Sourcebook. (2nd ed). Thousand Oaks: CA: Sage.

National Joint Committee on Learning Disabilities (2016). Learning disabilities: Issues on definition. 24 Ekim 2020 tarihinde https://www.ncld.org/research/state-of-learning-disabilities/ adresinden erişildi.

Onuk, D. (2017). Aile yaşam merkezlerinde verilen resim derslerinde hikaye anlatım yönteminin çocuk resimlerine etkisi. Yayınlanmamış yüksek lisans tezi, Gazi Üniversitesi, Ankara.

Özat, N. E. (2010). Öğrenme güçlüğü yaşayan çocuklarda frostig görsel algı eğitim programının etkisi. Yayınlanmamış yüksek lisans tezi, Abant İzzet Baysal Üniversitesi, Bolu.

Senese, V. P., Zappullo, I., Baiano, C., Zoccolotti, P., Monaco, M., ve Conson, M. (2020). Identifying neuropsychological predictors of drawing skills in elementary school children. Child Neuropsychology, 26(3), 345-361.

Yavuzer, H. (2017). Resimleriyle çocuk, resimleriyle çocuğu tanıma. İstanbul: Remzi Kitabevi 